\title{
Contents, Vol. 10, 1983
}

International Journal of Experimental and Clinical Research in

Biological Psychiatry, Pharmacopsychiatry, Biological Psychology/Pharmacopsychology and Pharmacoelectroencephalography

Official Journal of the International Pharmaco-EEG Group (IPEG)

Biological Psychiatry
Advisory Board

Main Editor

J. de Ajuriaguerra, Paris

J.J. Lopez Ibor, Madrid

J. Mendlewicz, Brussels

J. Angst, Zurich

P. Mandel, Strasbourg

O.H. Arnold, Vienna

M. Matejcek, Basel

Pharmacopsychiatry

M. Matousek, Göteborg

Main Editors

M. Bartels, Tubingen

N. Matussek, Munich

J. Fleischhauer, St. Urban/Luzern

P. Berner, Vienna

T. Nagatsu, Yokohama

Th.A. Ban, Nashville, Tenn.

J.R. Boîssier, Paris

CM. Pare, London |

P. Pîlchot, Paris

W. Boucsein, Wuppert

W. Pöldinger, Wil/St Gallen

M. Poldinger, Wil/St. Gallen

J.M. Perel, Pittsburgh, Pa

A. Coppen, Carshalton, Surrey

C. Peninis, Umeå

J.R. Davis, Chicago, 111

H. Petsche, Vienna

Main Editor

G. Debus, Aachen

A.J. Prange, Chapel Hill, N.C.

W. Janke, Würzburg

P. Deniker, Paris

M. Pritzel, Fribourg

Associate Editors

J.E. Desmedt, Brussels

O.J. Rafaelsen, Copenhagen

P. Netter Giessen

W.G. Dewhurst, Edmonton, Alta

.D. Rainer, New York, N.Y.

D.M. Warburton, Early Gate, Reading

A.E. Dresse, Liège

K. Rickels, Philadelphia, Pa.
I.R. Wittenborn, New Brunswick, N.J.

E. Ringel, Vienna

J. Durrell, Washington, D.C

T. Robbins, Cambridge 
Pharmacoelectroencephalography

R.C, Elston, Chapel Hill, N.C,

E.J. Sachar, Bronx, N.Y.

Main Editor

G. Künkel, Hannover

G. Erdmann, Berlin

H.J. Eysenck, London

M. Sandier, London

Associate Editors D. Bente, Berlin M. Fink, St. James, N.Y.

J. Fleisss, New York, N.Y.

N. Sartorius, Geneva

H.L. Freeman, Salford

M. Schou, Risskov

S. Garattini, Milan

F. Schulsinger, Copenhagen

H. Giledke, Tubingen

Ch. Shagass, Philadelphia, Pa. i

L.R. Gjessing, Oslo

J. Smythies, Birmingham, Ala.

J. Glowinski, Paris

E. Strömgren, Risskov

F.K. Goodwin, Bethesda, Md.

R. Takahashi, Nagasaki

J.A. Gray, Oxford

R. Tissot, Geneva

P. Grof, Hamilton, Ont

R. Tölle, Münste

O. Hagnell, Lund

E. Usdin, Irvine, Calif.

H. Heimann, Tubingen

L. Valzelli, Milan

T. Helgason, Reykjavik

H.M. Van Praag, Bronx, N.Y.

W.M. Herrmann, Berlin

M. Vartanian, Moscow

I. Hindmarch, Leed

A. Villeneuve, Beauport, Que.

F. Hoffmeister, Wuppertal-Elberfeld

O. Vinar, Prague

J.G. Howells, Ipswich

M. Vojtëchovsky, Prague

J.P. Huston, Düsseldor

G. Winokur, Iowa City, Iowa

T.M. Ml, New York, N.Y

B. Woggon, Zurich

H. İtoh, Tokyo

M.B.H. Youdim, Haifa!

P. Janssen, Beerse

E. Zerbin-Rüdin, Munich

F.N. Johnson, Lancaster 
M. Jouvet, Lyon

R. Kocher, Basel

W.P. Koella, Oberwil/Basel

H.-P. Krüger, Würzburg

St. Kubịcki, Berlin

J. Kugler, Munich

D. Kupfer, Pittsburgh, Pa

A.A. Kurland, Baltimore, Md.

M. Levitt, New York, N.Y.

G.A. Lienert, Nuremberg

M. Lipton, Chapel Hill, N.C.

S. Karger $\cdot$ Medical and Scientific Publishers $\cdot$ Basel $\cdot$ München $\cdot$ Paris $\cdot$ London $\cdot$ New York $\cdot$ Tokyo $\cdot$ Sydney

Drug Dosage

The authors and the publisher have exerted every effort to ensure that drug selection and dosage set forth in this text are in accord with current recommendations and practice at the time of publication. However, in view of ongoing research, changes in government regulations, and the constant flow of information relating to drug therapy and drug reactions, the reader is urged to check the package insert for each drug for any change in indications and dosage and for
added warnings and precautions. This is particularly important when the recommended agent is a new and/or infrequently employed drug. 
No part of this publication may be translated into other languages, reproduced or utilized in any form or by any means, electronic or mechanical, including photocopying, recording, microcopying, or by any information storage and retrieval system, without permission in writing from the publisher or, in the case of photocopying, direct payment of a specified fee to the Copyright Clearance Center (see 'Information for Readers and Subscribers')

(c) Copyright 1983 by

\section{Contents Vol. 10,1983}

No.1 
No, 2-3

Biological Psychiatry

Postictal Prolactin Elevations in Rats

Swartz, CM.; Dunbar, E.

Lithium Perspective

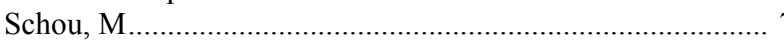

A Quantitative EEG Analysis of the Effects of Baclofen on

Man

Badr, G.G.; Matousek, M.; Frederiksen, P.K.

Pharmacopsychiatry

Compliance Testing by Measurement of Piracetam in Urine a Possible Method of Compliance Control for Piracetam Intakers. An Empirical Investigation

Fischer, B.; Lehrl, S.; Schnaiter, A.; Schulz, H.-U.; Salinger,

W.; Fischer, U.; Weber, E................................................... 19

Effect of Phenoxybenzamine on the GABA System and on

Convulsive Activity

Pericic, D.; Manev, $\mathrm{H}$

Biological Psychology/Pharmacopsychology

Drugs as Research Tools in Psychology: Experiments with

Drugs in Personality Research

Eysenck, H.J

Influence of Sensory Suggestibility on Treatment Outcome in

Headache Patients

Classen, W.; Feingold, E.; Netter, P ......................................... 44

Announcement .................................................................. 48

Pharmacoelectroencephalography

Crossover Designs and Repeated Measurements

Schneider, B

Baic Acid Treatment on Spike-Wave Discharge

Burr, W.; Stefan, H.; Kuhnen, C; Hoffmann, F.; Penin, H. . 56 Drug Effects on Sleep-Wakefulness Patterns in Dogs

Wauquier, A ........................................................................ 60 


\section{Biological Psychiatry}

Serum Cholesterol Levels in Homicidal Offenders. A Low

Cholesterol Level Is Connected with a Habitually Violent

Tendency under the Influence of Alcohol

Plasma Noradrenaline and Clinical Psychopathology in Schizophrenia. A Correlation Analysis

Dajas, F.; Barbeito, L.; Martinez-Pesquera, G.; Lista, A.;

Puppo, D.; Puppo-Touriz, H

Paranoiac Psychoses: A Follow-Up

Refsum, H.E.; Zivanovic, S.; Astrup, C

Mortality and Hidd M. A Pin , C............................

Age-Standardized Death Rates among Mentally 111 Study-

Patients' in a Total Population Observed during a 25-Year

Period

Rorsman, B.; Hagnell, O.; Lanke, J ...................................... 83

Treatment of the Organic Brain Syndrome in the Elderly. A

Double-Blind Comparison on the Effects of a Neurotropic

Drug and Placebo

Noel, G.; Jeanmart, M.; Reinhardt, B..................................... 90

Delta Sleep-Inducing Peptide in the Rat Brain: An Immunohis-tological Microscopic Study

Constantinidis, J.; Bouras, C; Guntern, R.; Taban, C.H.;

Tissot, R.

\section{Rapid Communication}

Circannual Variations in the Density of Tritiated Imipramine Binding Sites on Blood Platelets in Man Egrise, D.; Desmedt, D.; Schoutens, A.; Mendlewicz, J. . . 101

Pharmacopsychiatry

Influence

Physiological

Normal

of

Ogura,

Hazama,

hara, $\mathrm{K}$

H.;

Single

Measures

Young

Kishimoto,

Ryoke,
Doses

and

A.;

$\mathrm{K}$;
Psychomotor

and

Mizukawa,

Takeda,

$\begin{array}{lc}\text { and } & \text { Amitriptyline } \\ \text { Elderly } & \text { Performance } \\ \text { R.; } & \text { Kunimoto, } \\ \text { Honma, } & \text { H.; }\end{array}$

H.; on

Volunteers

N.; 
High Plasma Concentrations of Metoclopramide Are Not De tected by Radioreceptor Assay

Stanley, M.; Wazer, D.

/-Tryptophan in Hyperactive Child Syndrome Associated with

-Tryptophan in Hyperactive

Ghose, K

.....Ill

The Benzodis

15

Comparison of Chlormethiazole (Heminevrin) and Chlordiaz-epoxide (Librium) in the Treatment of Acute Alcohol Withdrawal

Lapierre, Y.D.; Bulmer, D.R.; Oyewumi, L.K.; Mauguin,

MX.; Knott, V.J .......................................................... 127

Depression-Inducing and Antidepressive Effects of Neurolep-

tics. Experiences with Flupenthixol and Flupenthixol Deca-

Pöldinger, W.; Sieberns, S

Organizing and Conducting Clinical Trials

Ban, T.A.; Guy, W.; Wilson, W.H.

Biological Psychology/Pharmacopsychology

The Many Facets of Poor Sleep

Knab, B.; Engel-Sittenfeld, P...

Activation and Anxiety as Represented by Patterns of Cate-

cholamine Levels in Hyper- and Normotensives

Netter, $\mathrm{P}$...

Curriculum vitae

Heinrich Düker: Pioneer in Pharmacopsychology 
Scheuler, W., Stinshoff, D.; Kubicki, S....

Effects of Beta-Receptor Blockers in Pharmacology EEG

Eschmann, G.; Irrgang, V.; Rüther, E......

No. 4

Biological Psychiatry

Saccadic Eye Movements in Psychiatric Patients

Schmid-Burgk, W.; Becker, W.; Jürgens, R.; Kornhuber,

H.H

Age-of-Onset in Schizophrenia and Schizotypal Disorders.

Clinical and Genetic Implications

Baron, M.; Gruen, R.; Asnis, L.; Kane, J

Successful Treatment of Withdrawal Symptoms with Delta

Sleep-Inducing Peptide, a Neuropeptide with Potential Ag

onistic Activity on Opiate Receptors

Dick, P.; Grandjean, M.E.; Tissot, R...

Pharmacopsychiatry

Effect of Nomifensine on Cortisol, Prolactin and Biogenic

Amines in Neurotic Depressed Patients

Rettori, V.; Rubio, M.; Seilicovich, A.; Malik, A.; Santos,

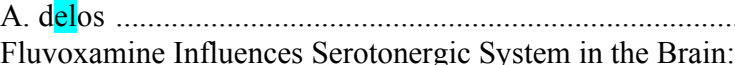

Fluvoxamine Influences Ser

Lapierre, Y.D.; Rastogi, R.B.; Singhal, R.L

Pharmacoelectroencephalography

The COMSTAT Algorithm for Multimodal Factor Analysis:

An Improvement of Tucker's Three-Mode Factor Analysis

Method

Röhmel, J.: Streitberg. B.; Herrmann, W.M

Example for Applying the COMSTAT Multimodal Factor

Analysis Algorithm to EEG Data to Describe Variance

Sources

Herrmann, W.M.; Röhmel. J.; Streitberg, B.; Willmann, J. . 164 Familiarization Session and Placebo Control in EEG Studies of

Drug Effects

Irwin, P.; Fink. M.

Co Adaptation to the Sleep Laboratory. Behavio

Sleep Organization, Quantitative EEG

Rosadini, G.. Consoli, D.; Ferrillo, F.: Rodriguez. G.: San-

nita, W. G. Silvestro, 
Biological Psychology/Pharmacopsychology

Behavioral Effects of Carbamazepine after Single and Repeated

Administration in Emotionally Labile Subjects

Janke, W.; Ehrhardt, K.J.; Munch, U ................

The Female Rat

Kleinlogel, $\mathrm{H}$

Book Review

Pharmacoelectroencephalography

EEG Monitoring in Anesthesiology and Intensive Care

Pichlmayr, I,

. .239

Correlation between EEG Changes Indicative of Sedation and

Subjective Responses

Vollmer, R.; Matejcek, M.; Greenwood, C; Grisold, W.;

Jellinger, K.

Author Index.

254

Subject Index .

...255

